\title{
Health-related quality of life of COPD patients aged over 40 years
}

\author{
V. FAZEKAS-PONGOR ${ }^{1}$, M. FEKETE ${ }^{1}$, P. BALAZS ${ }^{1}$, D. ÁRVA ${ }^{1}$, M. PÉNZES ${ }^{1}$, \\ S. TARANTINI ${ }^{2,3}$, R. URBÁN ${ }^{4}$ and J.T. VARGA ${ }^{5 *}$
}

${ }^{1}$ Department of Public Health, Faculty of Medicine, Semmelweis University, Budapest H-1085, Hungary

${ }^{2}$ University of Oklahoma Health Sciences Center, Department of Biochemistry and Molecular Biology, Oklahoma City, OK 73132, USA

${ }^{3}$ Department of Health Promotion Sciences, College of Public Health, University of Oklahoma Health Sciences Center, Oklahoma City, OK, USA

${ }^{4}$ Institute of Psychology, Eötvös Loránd University, Budapest H-1064, Hungary

${ }^{5}$ Department of Pulmonology, Semmelweis University, Budapest, Hungary

Received: February 8, 2021 - Accepted: April 27, 2021

Published online: June 21, 2021

(c) 2021 The Author(s)

\section{ABSTRACT}

Background: Chronic obstructive pulmonary disease (COPD) is the fourth most frequent disease globally, and its worldwide prevalence is projected to increase in the following decades. Health-related quality of life (HRQOL) of COPD patients depends on multiple factors. Objective: The aim of this study was to identify the most important risk factors affecting HRQOL of COPD patients and to measure how specific clinical parameters can predict HRQOL. Methods: A questionnaire-based cross-sectional study combined with clinical data was conducted among patients diagnosed with COPD $(n=321,52.6 \%$ females, mean age 66.4 \pm 9.5 ) at the National Koranyi Institute for Pulmonology, Budapest in 2019-2020. The inclusion criteria were age $\geq 40$ years and existing COPD. Multivariate linear regression analyses were conducted on three components of the COPD-specific Saint George's Respiratory Questionnaire (SGRQ-C) and on the physical (PCS) and mental component scales (MCS) of the 36-Item Short Form Health Survey (SF-36). Multiple linear regression analysis was performed to evaluate the effects of patient and disease characteristics on COPD Assessment Test (CAT) scores. Results: We found that frequent exacerbations, multiple comorbidities and tobacco smoking were associated with worse HRQOL. Engaging in more frequent physical activity and better 6-minute walking distance results were associated with better HRQOL. Conclusions: Our

* Corresponding author. Department of Pulmonology, Semmelweis University, Budapest, Hungary. Tel: +36 1 459 1500; fax: +36 1214 2498. E-mail: janosvargaster@gmail.com 
results indicate that the complex therapy of COPD should focus not only on improving lung functions and preventing exacerbation, but also on treating comorbidities, encouraging increased physical activity, and supporting smoking cessation to assure better HRQOL for patients.

\section{KEYWORDS}

chronic obstructive pulmonary disease, quality of life, SF-36, SGRQ-C, CAT

\section{INTRODUCTION}

Chronic obstructive pulmonary disease (COPD) is a progressive inflammatory condition of the lungs characterized by pulmonary symptoms, such as shortness of breath and/or cough, and extra-pulmonary manifestations, such as cachexia and/or systemic inflammation [1-3]. As of 2016, a total of 251 million people were affected by COPD worldwide, and the disease accounts for approximately $5 \%$ of global deaths yearly [4]. According to projections for future disease burden, COPD will be the $3^{\text {rd }}$ leading cause of death by 2030 [4], which may be partially linked to the growing proportion of elderly citizens in aging populations, as the risk of developing COPD increases with age [5]. The health-related quality of life (HRQOL) of COPD patients often depends on multiple factors. Thus, patients are usually affected by more than one comorbidity, such as cardiovascular diseases, diabetes, and osteoporosis [6]. Furthermore, the concurrent presence of certain other risk factors, like tobacco smoking, lower body weight, or lack of physical activity further worsen their HRQOL [7-9].

HRQOL measures the impact of a disease on the day-to-day functioning of patients [10]. According to recent protocols, the treatment model of COPD patients should focus not only on the evaluation of symptoms, but also on the improvement of patients' HRQOL [11]. Better quality life can be achieved by reducing the frequency of exacerbations, improving lung functions, and encouraging smoking cessation, body weight control, and regular physical activity $[6,7,12-14]$.

Studies indicate that the forced expiratory volume in one second $\left(\mathrm{FEV}_{1}\right)$ often correlates poorly with HRQOL, thus it doesn't account for extra-pulmonary manifestations of COPD, such as depression, anxiety, or the patients' ability to fulfil their daily duties [15]. As a result, instruments measuring HRQOL are often included in the assessment of COPD patients completing the classical clinical parameters. Thus, several general and disease-specific instruments can be used to quantify the HRQOL. For instance, the generic 36-Item Short Form Health Survey (SF-36) includes questions for eight separate HRQOL components [16]. Among the COPD-specific questionnaires, one of the most frequently used is the COPD-specific Saint George Respiratory Questionnaire (SGRQ-C) [17]. This instrument measures not only the severity of COPD symptoms but also the impact of the disease on the activity and everyday life of the patients. On the other hand, the COPD Assessment Test (CAT) focuses more on the effect of symptoms (e.g. cough, sputum, dyspnea, chest tightness) [18]. Even though both general and disease-specific indices are widely used to assess HRQOL among COPD patients, the SGRQ-C is more reliable in differentiating among patients concerning changes in COPD disease severity over time compared to other instruments [19].

The complex management of COPD should focus not only on lung function values, other functional variables, and exacerbation rates but also on the improvement of the patients' 
HRQOL. In the next decades, COPD is projected to increasingly affect the HRQOL of the global population. Therefore, the goals of our study were (1) to identify risk factors influencing HRQOL of COPD patients and (2) to measure how specific clinical parameters are associated to HRQOL.

\section{MATERIALS AND METHODS}

\section{Participants and procedure}

A cross-sectional study was performed among COPD patients at an inpatient department of the Hungarian National Koranyi Institute for Pulmonology, Budapest in 2019-2020. Inclusion criteria were age $\geq 40$ years and recognized COPD (post-bronchodilator $\mathrm{FEV}_{1} / \mathrm{FVC}<70 \%$ ). Exclusion criteria were simultaneous asthma, malignant diseases, and/or autoimmune diseases in terms of ICD-10 definitions. Participation was voluntary, and before signing the consent document, all patients were informed verbally and in writing about the study and its purpose. An appointed coordinator conducted the questionnaire-based interviews and filled out the questionnaires according to the patients' answers in a timeframe of 30 minutes. Clinical examination of patients followed the completion of the questionnaire, generally on the same day. Altogether 321 patients were approached and all of them agreed to participate in the study. The study protocol and the study were approved by the Ethical Committee of the National Koranyi Institute for Pulmonology (25/2017) and the Institutional Review Board of Semmelweis University (TUKEB 44402-2/2018/EKU) in compliance with the Helsinki Declaration.

\section{Measurement}

Our questionnaire contained items exploring the patients' socio-demographic, lifestyle, and disease-specific characteristics. Specific items included age, gender, COPD exacerbation in the past year (yes/no), body mass index (BMI), current smoking status (yes/no), frequency of physical activity ( $\leq 1$ time a week/ $\geq 2$ times a week), and number of comorbidities. Exacerbation was defined as an acute and significant change of the patient's daily symptoms resulting in change of therapy. As noted by Guo et al., BMI for COPD is more consistent if BMI is categorized as $\leq 21,21.1-29.99$, and $\geq 30$ compared to the traditional categories of $<18.49,18.5-25.0$, and $>25.1$ [20]. To be able to include BMI in our analysis, we used two separate dummy variables to examine the effect of obesity $(\mathrm{BMI} \geq 30$ vs. reference $\mathrm{BMI} \leq 29.9)$ and underweight $(\mathrm{BMI} \leq 21$ vs. reference $\mathrm{BMI} \geq 21.1)$ as risk factors. Regarding comorbidities, cardiovascular diseases, diabetes, immunological diseases, osteoporosis, musculoskeletal diseases, psychiatric diseases, allergies, hypersensitivities, and gastrointestinal diseases were included in the analysis. Data on comorbidities, lung function values, and BMI were collected from the latest medical records from the past month. Presence of exacerbation was examined from medical records dating back one year. All other data were collected with questionnaires.

HRQOL was measured by SGRQ-C, COPD Assessment Test (CAT) and Short Form Health Survey (SF-36) instruments. The SGRQ-C instrument consists of 40 questions divided into three separate components. The symptoms component describes the frequency and severity of symptoms over the past three months, the activity component measures the impact of breathlessness on activities, whereas the impact component describes the effect of the disease on social 
functioning and mental health of patients [17]. Scores range from 0 to 100 with higher scores indicating more severe symptoms/limitations [17]. CAT is a unidimensional tool, consisting of eight items with six response options for each question [18]. Scores range from 0 (best) to 40 (worst) [18]. Finally, SF-36 contains 36 questions measuring eight separate components related to quality of life (physical functioning, role limitation-physical, role limitation-emotional, vitality, mental health, social functioning, pain, and general health) [16]. Results range from 0 (worst) to 100 (best) [16]. We decided to calculate two subscales derived from the SF-36 scale, namely the physical (PCS) and mental (MCS) component scales to decrease the number of concurrent comparisons. Therefore, we standardized each of the eight components of SF-36 with a Z-score transformation. Individual Z-scores were calculated by subtracting the population mean from the respondents' score and dividing it by the standard deviation. For both the PCS and MCS scales, scores were multiplied by weighting coefficients calculated from a USA population and standardized to a T-score with means set at 50 and standard deviation set at 10 [21].

Patients were assigned to one of the Global Initiative for Chronic Obstructive Lung Disease (GOLD) stages based on their $\mathrm{FEV}_{1}$ results, as measured after the completion of the questionnaire according to the following specifications: $\mathrm{FEV}_{1} \geq 80 \%$ as stage $1,50-80 \%$ as stage 2,30 $50 \%$ as stage 3 , and $\leq 30 \%$ as stage 4 [22]. The $\mathrm{FEV}_{1}$, FVC (forced vital capacity), and $\mathrm{FEV}_{1} / \mathrm{FVC}$ values were measured by spirometry [23]. Exercise capacity was assessed by the 6-minute walking distance $(6 \mathrm{MWD})$ test $[24,25]$. We requested patients to walk up and down a hallway with predefined turning points for a total of 6 minutes. Results were measured in meters.

\section{Statistical analysis}

Socio-demographic characteristics and HRQOL scores by gender were analyzed with Pearson's Chi-square test, independent samples t-tests, and Mann-Whitney U-test. Normality was assessed by Shapiro-Wilk's normality test. Bivariate correlational analyses were performed for the three components (symptoms, activity, and impact) and for the total score of SGRQ-C, CAT, and the PCS and MCS scales of SF-36 by including individual variables in our models one at a time. This was followed by multivariate linear regression analyses for different components of the SGRQ-C and SF-36 questionnaires and multiple linear regression analysis for the unidimensional CAT questionnaire by including all variables in each respective model. Multivariate regression analysis was used for SGRQ-C and SF-36 as both are multidimensional tools and are comprised of more than one dependent variable, whereas multiple linear regression analysis was used for CAT as it is a unidimensional instrument with a single dependent variable. Maximum likelihood estimation with robust standard error was used to calculate regression coefficients. Results of the correlation matrices of each analysis were presented as well. We evaluated the effect of gender, age, smoking, physical activity, BMI, exacerbations, comorbidities, $\mathrm{FEV}_{1} / \mathrm{FVC}$, and 6MWD results on HRQOL scores in our linear regression analyses. For each model, $R^{2}$ values were calculated to describe the proportion of explained variance. Significance was set at $P<0.05$. All analyses were conducted in $\mathrm{R}$ statistics (lavaan package).

\section{RESULTS}

Table 1 shows the descriptive characteristics of the sample. Compared to males (47.4\%), females (52.6\%) had significantly higher BMI, greater number of comorbidities, and lower 6MWD 
Table 1. Sociodemographic, disease-specific, and quality of life characteristics of the sample by gender $(n=321)$

\begin{tabular}{|c|c|c|c|c|}
\hline \multirow[b]{2}{*}{ Variables } & \multicolumn{4}{|c|}{ Participants } \\
\hline & Total $(n=321)$ & Male $(n=152)$ & Female $(n=169)$ & $P$-value \\
\hline Age (years), mean (SD) & $66.4(9.5)$ & $65.8(9.4)$ & $67.0(9.7)$ & 0.363 \\
\hline BMI $\left(\mathrm{kg} / \mathrm{m}^{2}\right)$, mean $(\mathrm{SD})$ & $26.0(7.0)$ & $24.7(6.3)$ & $27.2(7.4)$ & 0.003 \\
\hline BMI, n (\%) & & & & 0.036 \\
\hline$\leq 21$ & $82(26)$ & $47(31)$ & $35(21)$ & \\
\hline $21.1-29.99$ & $140(45)$ & $69(46)$ & $71(44)$ & \\
\hline$\geq 30$ & $92(29)$ & $35(23)$ & $57(35)$ & \\
\hline Physical activity $\geq 2$ times/week, n (\%) & $65(20)$ & $34(22)$ & $31(18)$ & 0.405 \\
\hline Current smoker, n (\%) & $137(44)$ & $70(47)$ & $67(41)$ & 0.306 \\
\hline Exacerbation in the past year, $\mathrm{n}(\%)$ & $165(51)$ & $82(54)$ & $83(49)$ & 0.434 \\
\hline Comorbidities $(\mathrm{n})$, mean $(\mathrm{SD})$ & $2.14(1.7)$ & $1.91(1.7)$ & $2.35(1.7)$ & 0.009 \\
\hline GOLD stages, $\mathrm{n}(\%)$ & & & & 0.200 \\
\hline Stage 1 & $26(9)$ & $8(6)$ & $18(12)$ & \\
\hline Stage 2 & $98(34)$ & $49(36)$ & $49(31)$ & \\
\hline Stage 3 & $120(41)$ & $52(39)$ & $68(43)$ & \\
\hline Stage 4 & $48(16)$ & $26(19)$ & $22(14)$ & \\
\hline $\mathrm{FEV}_{1} / \mathrm{FVC}(\%)$, mean $(\mathrm{SD})$ & $53.4(13.1)$ & $51.7(12.7)$ & $55.0(13.4)$ & 0.054 \\
\hline 6MWD $(\mathrm{m})$, mean $(\mathrm{SD})$ & $265(133)$ & $307(136)$ & $226(118)$ & $<0.001$ \\
\hline \multicolumn{5}{|l|}{ SGRQ-C, mean (SD) } \\
\hline Symptom & $67.1(20.2)$ & $66.3(21.4)$ & $67.7(19.1)$ & 0.747 \\
\hline Activity & $65.9(24.2)$ & $60.8(25.3)$ & $70.6(22.2)$ & $<0.001$ \\
\hline Impact & $53.9(24.9)$ & $48.2(26.5)$ & $59.0(22.2)$ & $<0.001$ \\
\hline Total & $59.9(21.4)$ & $55.3(23.0)$ & $64.1(18.9)$ & $<0.001$ \\
\hline CAT, mean $(\mathrm{SD})$ & $24.8(8.8)$ & $23.8(8.7)$ & $25.7(8.7)$ & 0.036 \\
\hline \multicolumn{5}{|l|}{ SF-36, mean (SD) } \\
\hline PCS & $33.1(8.5)$ & $35.0(8.3)$ & $31.4(8.2)$ & $<0.001$ \\
\hline MCS & $42.8(11.3)$ & $43.3(11.4)$ & $42.2(11.1)$ & 0.395 \\
\hline
\end{tabular}

Note: Pearson Chi-Square test or independent samples t test or Mann-Whitney test $P$-values were used to examine the differences between males and females.

BMI: body mass index; CAT: COPD Assessment Test; COPD: chronic obstructive pulmonary disease; $\mathrm{FEV}_{1}$ : forced expiratory volume in the first second; FVC: forced vital capacity; GOLD: Global Initiative for Chronic Obstructive Lung Disease; MCS: mental component scale; 6MWD: 6-minute walking distance; PCS: physical component scale; SD: standard deviation; SF-36: 36-Item Short Form Survey; SGRQ-C: COPD-specific Saint George Respiratory Questionnaire.

results. Regarding HRQOL, females reported poorer HRQOL according to the activity and impact components, and total scores of SGRQ-C. Furthermore, the mean score of the PCS of SF36 was also significantly lower among them than among males, whereas their mean score of CAT was significantly higher.

In the multivariate analysis of SGRQ-C (Table 2), we found that current smokers had higher scores on the symptom subscale $(\beta=0.11, P<0.05)$, more comorbidities correlated with higher activity scores $(\beta=0.13, P<0.01)$ and total scores $(\beta=0.09, P<0.05)$. The occurrence of exacerbations in the past year was associated with an increased score on the symptoms 
Table 2. Predictors of the COPD-specific Saint George Respiratory Questionnaire's (SGRQ-C) three domains and total score $(n=280)$

\begin{tabular}{|c|c|c|c|c|c|c|c|c|}
\hline & \multicolumn{4}{|c|}{ Bivariate correlations } & \multicolumn{4}{|c|}{ Multivariate regression analysis } \\
\hline & $\begin{array}{c}\text { Symptoms } \\
r\end{array}$ & $\begin{array}{c}\text { Activity } \\
r\end{array}$ & $\begin{array}{c}\text { Impact } \\
r\end{array}$ & $\begin{array}{c}\text { Total } \\
r\end{array}$ & $\begin{array}{c}\text { Symptoms } \\
\beta\end{array}$ & $\begin{array}{c}\text { Activity } \\
\beta\end{array}$ & $\begin{array}{c}\text { Impact } \\
\beta\end{array}$ & $\begin{array}{c}\text { Total } \\
\beta\end{array}$ \\
\hline Gender & 0.05 & $0.21^{* * *}$ & $0.20^{* * *}$ & $0.20^{\star * \star}$ & -0.00 & 0.06 & 0.09 & 0.07 \\
\hline Age & 0.02 & $0.19^{\star *}$ & 0.06 & 0.10 & -0.03 & 0.04 & -0.05 & -0.02 \\
\hline Smoking & $0.14^{*}$ & -0.02 & 0.07 & 0.06 & $0.11^{\star}$ & -0.02 & 0.04 & 0.04 \\
\hline Physical activity & $-0.16^{* *}$ & $-0.34^{\star * *}$ & $-0.29^{\star * *}$ & $-0.32^{* * *}$ & $-0.11^{\star}$ & $-0.28^{\star * *}$ & $-0.24^{\star * *}$ & $-0.26^{* * *}$ \\
\hline Underweight & $0.14^{*}$ & 0.06 & 0.09 & 0.10 & 0.06 & 0.02 & 0.04 & 0.04 \\
\hline Obesity & -0.09 & 0.01 & -0.01 & -0.02 & -0.08 & -0.03 & -0.06 & -0.06 \\
\hline Comorbidities & $0.18^{\star *}$ & $0.23^{* * *}$ & $0.15^{*}$ & $0.20^{* * *}$ & 0.10 & $0.13^{* *}$ & 0.05 & $0.09^{*}$ \\
\hline Exacerbation & $0.42^{* * *}$ & $0.33^{* * *}$ & $0.37^{* * *}$ & $0.41^{\star * *}$ & $0.35^{* * *}$ & $0.20^{\star * *}$ & $0.28^{\star * *}$ & $0.29^{* * *}$ \\
\hline $\mathrm{FEV}_{1} / \mathrm{FVC}$ & -0.10 & $-0.16^{\star *}$ & -0.08 & $-0.12^{\star}$ & 0.05 & -0.01 & 0.08 & 0.05 \\
\hline 6MWD & $-0.28^{* * *}$ & $-0.50^{\star * *}$ & $-0.43^{* * *}$ & $-0.48^{\star * *}$ & $-0.19^{* *}$ & $-0.37^{\star * *}$ & $-0.34^{\star \star *}$ & $-0.36^{* * *}$ \\
\hline$R^{2}$ & N/A & N/A & N/A & N/A & $26.0 \%$ & $39.7 \%$ & $34.2 \%$ & $41.0 \%$ \\
\hline
\end{tabular}

Note: ${ }^{\star} P<0.05 ;{ }^{* *} P<0.01 ;{ }^{* *} P<0.001$. Multivariate regression. $\beta$ : standardized regression coefficient; $\mathrm{FEV}_{1}$ : forced expiratory volume in the first second, FVC: forced vital capacity; 6MWD: 6-minute walking distance; $R^{2}$ : proportion of explained variance; $r$ : Pearson's correlation. 
Table 3. Predictors of the COPD Assessment Test (CAT) $(n=280)$

\begin{tabular}{lcc}
\hline & \multicolumn{2}{c}{ COPD Assessment Test } \\
\cline { 2 - 3 } Variables & $r$ & $\beta^{*}$ \\
\hline Gender & $0.13^{*}$ & 0.05 \\
Age & 0.01 & -0.06 \\
Smoking & 0.11 & 0.08 \\
Physical activity & $-0.18^{*}$ & $-0.14^{*}$ \\
Underweight & 0.11 & 0.07 \\
Obesity & -0.02 & -0.03 \\
Comorbidities & $0.23^{* * *}$ & $0.16^{*}$ \\
Exacerbation & $0.31^{* * *}$ & $0.23^{* * *}$ \\
FEV $/$ FVC & -0.11 & 0.01 \\
6MWD & $-0.30^{* * *}$ & $-0.21^{* *}$ \\
$R^{2}$ & N/A & $21.8 \%$ \\
\hline
\end{tabular}

Note: ${ }^{\star} P<0.05 ;{ }^{* *} P<0.01 ;{ }^{* *} P<0.001 .{ }^{*}$ : Multiple regression analysis. $\beta$ : standardized regression coefficient; $\mathrm{FEV}_{1}$ : forced expiratory volume in the first second, FVC: forced vital capacity, 6MWD: 6minute walking distance; $R^{2}$ : proportion of explained variance; $r$ : Pearson's correlation.

$(\beta=0.35, P<0.001)$, activity $(\beta=0.20, P<0.001)$, impact $(\beta=0.28, P<0.001)$ subscales and total scale $(\beta=0.29, P<0.001)$. Conversely, more frequent physical activity and better $6 \mathrm{MWD}$ correlated with lower scores on the symptoms $(\beta=-0.11, P<0.05$ and $\beta=-0.19, P<0.01$, respectively), activity $(\beta=-0.28, P<001$ and $\beta=-0.37, P<0.001$, respectively), impact

Table 4. Predictors of the 36-Item Short Form Survey (SF-36) of COPD patients $(n=257)$

\begin{tabular}{|c|c|c|c|c|}
\hline \multirow[b]{2}{*}{ Variables } & \multicolumn{2}{|c|}{ Bivariate correlations } & \multicolumn{2}{|c|}{$\begin{array}{c}\text { Multivariate regression } \\
\text { analysis }\end{array}$} \\
\hline & $\begin{array}{c}\text { PCS } \\
r\end{array}$ & $\begin{array}{c}\mathrm{MCS} \\
r\end{array}$ & $\begin{array}{c}\mathrm{PCS} \\
\beta\end{array}$ & $\begin{array}{c}\mathrm{MCS} \\
\beta\end{array}$ \\
\hline Gender & $-0.20^{\star *}$ & -0.03 & -0.12 & 0.04 \\
\hline Age & $-0.14^{\star}$ & 0.07 & -0.04 & 0.10 \\
\hline Smoking & 0.06 & $-0.15^{\star}$ & 0.06 & -0.09 \\
\hline Physical activity & $0.19^{\star *}$ & $0.16^{\star *}$ & $0.12^{*}$ & $0.13^{*}$ \\
\hline Underweight & -0.06 & -0.11 & -0.05 & -0.08 \\
\hline Obesity & -0.05 & 0.00 & -0.03 & 0.01 \\
\hline Comorbidities & -0.09 & $-0.13^{*}$ & 0.01 & -0.09 \\
\hline Exacerbation & $-0.28^{\star \star \star}$ & $-0.23^{\star \star \star}$ & $-0.21^{\star \star \star}$ & $-0.16^{\star}$ \\
\hline $\mathrm{FEV}_{1} / \mathrm{FVC}$ & $0.13^{*}$ & 0.03 & 0.03 & -0.08 \\
\hline 6MWD & $0.38^{* * *}$ & $0.22^{* * *}$ & $0.26^{* * *}$ & $0.20^{\star *}$ \\
\hline$R^{2}$ & N/A & N/A & $22.1 \%$ & $13.7 \%$ \\
\hline
\end{tabular}

Note: ${ }^{\star} P<0.05 ;{ }^{\star \star} P<0.01 ;{ }^{\star \star \star} P<0.001$. Multivariate regression. $\beta$ : standardized regression; $\mathrm{FEV}_{1}$ : forced expiratory volume in the first second, FVC: forced vital capacity; MCS: mental component scale; 6MWD: 6minute walking distance; PCS: physical component scale; $R^{2}$ : proportion of explained variance; $r$ : Pearson's correlation. 
Table 5. Correlational matrix of quality of life indices $(n=296)$

\begin{tabular}{|c|c|c|c|c|c|c|c|}
\hline \multirow[b]{2}{*}{ Index } & \multicolumn{4}{|c|}{ SGRQ-C } & \multirow[b]{2}{*}{ CAT } & \multicolumn{2}{|c|}{ SF-36 } \\
\hline & Symptoms & Activity & Impact & Total & & MCS & PCS \\
\hline SGRQ-C Symptoms & 1.00 & & & & & & \\
\hline SGRQ-C Activity & $0.54^{\star}$ & 1.00 & & & & & \\
\hline SGRQ-C Impact & $0.63^{\star}$ & $0.73^{\star}$ & 1.00 & & & & \\
\hline SGRQ-C Total & $0.73^{\star}$ & $0.87^{\star}$ & $0.96^{*}$ & 1.00 & & & \\
\hline CAT & $0.55^{\star}$ & $0.45^{\star}$ & $0.49^{*}$ & $0.54^{\star}$ & 1.00 & & \\
\hline SF-36 MCS & $-0.39^{\star}$ & $-0.32^{\star}$ & $-0.43^{\star}$ & $-0.57^{\star}$ & $-0.43^{\star}$ & 1.00 & \\
\hline SF-36 PCS & $-0.34^{*}$ & $-0.55^{\star}$ & $-0.54^{\star}$ & $-0.43^{*}$ & $-0.29^{\star}$ & 0.02 & 1.00 \\
\hline
\end{tabular}

Note: Pearson's correlation. ${ }^{\star} P<0.001$.

SGRQ-C: COPD-specific Saint George Respiratory Questionnaire; CAT: COPD Assessment Test; SF-36: 36-Item Short Form Survey; MCS: mental component scale; PCS: physical component scale.

( $\beta=-0.24, P<0.001$ and $\beta=-0.34, P<0.001$, respectively) subscales and total scale ( $\beta=-0.26, P<0.001$ and $\beta=-0.36, P<0.001$, respectively).

Analysis of CAT indicated that increased frequency of physical activity $(\beta=-0.14, P<0.05)$ and better results on the $6 \mathrm{MWD}$ test $(\beta=-0.21, P<0.01)$ were inversely associated with CAT scores, whereas comorbidities $(\beta=0.16, P<0.05)$ and exacerbations $(\beta=0.23, P<0.001)$ were in direct association with CAT scores (Table 3).

In the analysis of PCS and MCS of SF-36 (see Table 4), we found that higher frequency of physical activity $(\beta=0.12, P<0.05$ and $\beta=0.13, P<0.05$, respectively) and better results on the 6 MWD test ( $\beta=0.26, P<0.001$ vs. $\beta=0.20, P<0.01$, respectively) were positively correlated with both scores. However, manifest exacerbations in the past year resulted lower scores on PCS $(\beta=-0.21, P<0.001)$ and $\operatorname{MCS}(\beta=-0.16, P<0.05)$.

When we examined the correlations of individual HRQOL indices with each other, they were significant except that between MCS and PCS. In the correlation matrix, SF-36 (PCS, MCS) scores were inversely related to both SGRQ-C and CAT questionnaires because of the opposite scoring methods employed (Table 5).

\section{DISCUSSION}

Our study established that the occurrence of COPD exacerbations, simultaneous comorbidities, and smoking were the most important factors negatively affecting the COPD patients' HRQOL, whereas the frequency of physical activity and better results on the 6MWD test were positively associated with their HRQOL. The correlation between SGRQ-C, CAT and SF-36 questionnaires was fair, indicating that these questionnaires examine slightly different aspects of HRQOL.

Our sample revealed poorer results as measured by the SGRQ-C, CAT, and SF-36 instruments compared to the results of other studies measuring the HRQOL of COPD patients [26-28]. According to the OECD, Hungary ranks in the bottom $20 \%$ in health and life satisfaction [29]. Additionally, smoking rates are among the highest in Europe, along with higher rates of alcohol consumption and overweight/obesity, and somewhat poorer performance in 
terms of physical activity [30]. These factors, both individually and overall, may affect HRQOL while offering a possible explanation for our results and also explaining why mortality of COPD in Hungary ranks the highest in Europe [31].

In our study, the number of exacerbations and comorbidities were strongly related to worse HRQOL. Severe manifestations of COPD are often associated with more frequent exacerbations, which may have a strong impact on the day-to-day functioning of patients [12]. According to Miravitlles et al., HRQOL decreases substantially just after an exacerbation, but it tends to improve fairly quickly within days of the event [12]. However, negative effects of exacerbations on HRQOL seem to accumulate over time, explaining why patients with more exacerbations tend to have a lower HRQOL compared to stable patients with fewer events. As for comorbidities, patients with COPD are often aged individuals and are affected by a plethora of other conditions as well, such as cardiovascular diseases, malnutrition, depression, and anxiety, that may also affect their activities and functioning [32]. A previous study identified psychiatric disorders and peripheral artery diseases as the most important comorbidities with negative impact on HRQOL of COPD patients [33]. Our results highlight that effective tertiary prevention along with treatment of any comorbid conditions may be essential for the improvement of HRQOL.

Regarding lifestyle factors, we found that HRQOL was significantly affected by physical activity and smoking. Studies indicate that the improvement of physical fitness during rehabilitation leads to improved functional parameters of COPD patients [34-36]. In our study, physical activity improved all dimensions of HRQOL and also had a positive effect on the mental health of patients. According to the WHO, 150 minutes of moderate-intensity aerobic physical activity or at least 75 minutes of vigorous-intensity aerobic physical activity is advised per week for the maintenance of health between ages 18 and 65 [35, 37]. For patients over 65, counseling should focus more on the importance of leisure time physical activity, transportation, household chores, and gardening for the same amount of time as specified above [37]. Regarding smoking, physicians offering smoking cessation support for COPD patients should emphasize that quitting will positively impact the severity of symptoms, which in turn will also improve their overall HRQOL.

In our study the $\mathrm{FEV}_{1} / \mathrm{FVC}$ index did not correlate with HRQOL, suggesting that it in independent of lung capacity values to a certain extent. This is corroborated by other studies which detected only modest association between $\mathrm{FEV}_{1}$ or $\mathrm{FEV}_{1} / \mathrm{FVC}$ values and changes in health status and other disease outcomes [15, 38], such as rate of exacerbations [39]. The results are, however, often inconsistent [6]. Namely, in the bivariate model we found that higher $\mathrm{FEV}_{1} /$ FVC values were associated with improved outcomes on the activity component and total scores of SGRQ-C, although this association disappeared when we controlled for additional factors. The 6MWD results were positively associated with all components of HRQOL. Since physical activity is strongly associated with 6MWD [40], the latter can be used to assess patients' level of fitness and also give an insight for physicians in the HRQOL of their patients [41, 42].

One of the strengths of our study is that we measured HRQOL with three different methods, and we compared them with clinical/diagnostic test outcomes. Having included all variables in the models, $R^{2}$ values were relatively high. This indicates that these variables explain the variance in our study population fairly well, suggesting that exacerbations, physical activity, and number of comorbidities affect the HRQOL of COPD patients to a greater extent.

Finally, we must also take into consideration certain limitations of our study, for example the relatively small sample and the single-center involvement. Since we examined hospitalized 
in-patients, our study sample may have contained a higher proportion of patients with more severe forms of COPD and thus, worse health-related quality of life. The role of selection bias cannot be ruled out since the participation was voluntary, which explains the better HRQOL outcomes of the sample. It may also have been useful to evaluate comorbidities with a multidimensional comorbidity index rather than the total number of comorbidities. An additional limitation was that in the calculation of MCS and PCS scores, weighting coefficients calculated from the Hungarian general population were not available, therefore we had to rely on coefficients calculated from the general USA population. This may have led to biased results for SF-36 even though certain studies suggest that this is a viable option when lacking populationspecific estimates, as it produces similar results [43].

$\mathrm{COPD}$ is a progressive, multi-organ disease that requires a more complex treatment strategy due to its diverse effects on the body and the health-related quality of life of the patients. In this study, the most important factors negatively affecting HRQOL were frequent exacerbations, number of comorbidities, the lack of physical activity, and current smoking. Regarding clinical parameters, we found a consistent positive effect between 6MWD and all components of HRQOL. The treatment model of patients should focus not only on lung function improvement and the prevention of exacerbations but also on the management of comorbidities, complemented with suggesting physical activity and smoking cessation.

Funding: This work received no funding from outside source.

Disclosure of interest: The authors report no conflict of interest.

Data availability statement: The data that support the findings of this study are available on request from the corresponding author [JTV].

\section{REFERENCES}

1. Barnes PJ, Celli BR. Systemic manifestations and comorbidities of COPD. Eur Respir J 2009; 33: $1165-85$. https://doi.org/10.1183/09031936.00128008.

2. Egészségügyi Szakmai Kollégium. Egészségügyi szakmai irányelv - A krónikus obstruktív tüdőbetegség (chronic obstructive pulmonary disease - COPD) diagnosztikájáról, kezeléséröl és gondozásáról [Health professionals' directive - About the diagnosis, treatment and management of chronic obstructive pulmonary disease]. Budapest: Emberi Erőforrások Minisztériuma-Egészségügyért Felelős Államtitkárság; 2017 [cited 2020 Jan 21]; [63 p.] Directive No. 001049. Hungarian. Available at: https://kollegium.aeek.hu/Download/ Download/2253.

3. Varga J, Palinkas A, Lajko I. Pulmonary arterial pressure response during exercise: a correlation with Creactive protein. Open Respir Med J 2016; 10: 1-11. https://doi.org/10.2174/1874306401610010001.

4. Mathers CD, Loncar D. Projections of global mortality and burden of disease from 2002 to 2030. PloS Med 2006; 3(11): e442. https://doi.org/10.1371/journal.pmed.0030442.

5. Fukuchi Y. The aging lung and chronic obstructive pulmonary disease: similarity and difference. Proc Am Thorac Soc 2009; 6: 570-2. https://doi.org/10.1513/pats.200909-099RM. 
6. Zamzam MA, Azab NY, El Wahsh RA, Ragab AZ, Allam EM. Quality of life in COPD patients. Egypt J Chest Dis Tuberc 2012; 61: 281-9. Available from: http://dx.doi.org/10.1016/j.ejcdt.2012.08.012.

7. Wytrychiewicz K, Pankowski D, Janowski K, Bargiel-Matusiewicz K, Dạbrowski J, Fal AM. Smoking status, body mass index, health-related quality of life, and acceptance of life with illness in stable patients with COPD. Front Psychol 2019; 10: 1526. Available from: https://doi.org/10.3389/fpsyg.2019.01526.

8. Ran P, Wang C, Yao W, Chen P, Kang J, Huang SG. A study on the correlation of body mass index with chronic obstructive pulmonary disease and quality of life. Zhonghua Jie He He Hu Xi Za Zhi 2007; 30: 18-22. Chinese. PMID: 17326967.

9. Alison JA, McKeough ZJ. Exercise and quality of life in COPD. In: Preedy VR, Watson RR, editors. Handbook of disease burdens and quality of life measures. New York (NY): Springer New York; 2010 [cited 2020 Jun 8]. p. 4119-4131. Available at: http://link.springer.com/10.1007/978-0-387-78665-0_240.

10. Karimi M, Brazier J. Health, health-related quality of life, and quality of life: what is the difference? PharmacoEconomics 2016; 34: 645-9. https://doi.org/10.1007/s40273-016-0389-9.

11. Global Initiative for Chronic Obstructive Lung Disease (GOLD). Global strategy for the diagnosis, management and prevention of chronic obstructive pulmonary disease; 2019 [cited 2020 Jun 30]. Available at: https://goldcopd.org/wp-content/uploads/2018/11/GOLD-2019-v1.7-FINAL-14Nov2018-WMS.pdf.

12. Miravitlles M. Effect of exacerbations on quality of life in patients with chronic obstructive pulmonary disease: a 2 year follow up study. Thorax 2004; 59: 387-95. https://doi.org/10.1136/thx.2003.008730.

13. Esteban C, Quintana JM, Aburto M, Moraza J, Egurrola M, Pérez-Izquierdo J. Impact of changes in physical activity on health-related quality of life among patients with COPD. Eur Respir J 2010; 36: 292-300. Available from: https://doi.org/10.1183/09031936.00021409.

14. Cheruvu VK, Odhiambo LA, Mowls DS, Zullo MD, Gudina AT. Health-related quality of life in current smokers with COPD: factors associated with current smoking and new insights into sex differences. Int J Chron Obstruct Pulmon Dis 2016; 11: 2211-9. Available from: https://doi.org/10.2147/COPD.S106207.

15. Jones P, Miravitlles M, van der Molen T, Kulich K. Beyond FEV1 in COPD: a review of patient-reported outcomes and their measurement. Int J Chron Obstruct Pulmon Dis 2012; 697. Available from: https://doi. org/10.2147/COPD.S32675.

16. Hooker SA. SF-36. In: Gellman MD, Turner JR, editors. Encyclopedia of behavioral medicine. New York (NY): Springer New York; 2013 [cited 2020 Jan 21]. p. 1784-1786. Available at: http://link.springer.com/10. 1007/978-1-4419-1005-9_1597.

17. Meguro M, Barley EA, Spencer S, Jones PW. Development and validation of an improved, COPD-specific version of the St. George respiratory questionnaire. Chest 2007; 132: 456-63. Available from: https://doi.org/ 10.1378/chest.06-0702.

18. Jones PW, Harding G, Berry P, Wiklund I, Chen WH, Kline Leidy N. Development and first validation of the COPD assessment test. Eur Respir J 2009; 34: 648-54. Available from: https://doi.org/10.1183/09031936. 00102509.

19. Pickard AS, Yang Y, Lee TA. Comparison of health-related quality of life measures in chronic obstructive pulmonary disease. Health Qual Life Outcomes 2011; 9: 26. https://doi.org/10.1186/1477-7525-9-26.

20. Guo Y, Zhang T, Wang Z, Yu F, Xu Q, Guo W, et al. Body mass index and mortality in chronic obstructive pulmonary disease: a dose-response meta-analysis. Medicine (Baltimore) 2016; 95: e4225. Available from: https://doi.org/10.1097/MD.0000000000004225.

21. Ware JE, Kosinski M, Keller SK. Physical and mental health summary scales. A user's manual. Boston, MA: The Health Institute; 1994. Available at: https:/www.researchgate.net/profile/John-Ware-6/publication/ 292390260_SF-36_Physical_and_Mental_Health_Summary_Scales_a_User\%27s_Manual/links/ 5af580264585157136caee31/SF-36-Physical-and-Mental-Health-Summary-Scales-a-Users-Manual.pdf. 
22. Hernández M, García G, Falco J, García AR, Martín V, Ibarrola M. Impact of using the new GOLD classification on the distribution of COPD severity in clinical practice. Int J Chron Obstruct Pulmon Dis 2018; 13: 351-6. Available from: https://doi.org/10.2147/COPD.S112551.

23. Quanjer PH, Tammeling GJ, Cotes JE, Pedersen OF, Peslin R, Yernault JC. Lung volumes and forced ventilatory flows. Report working party standardization of lung function tests, European Community for Steel and Coal. Official statement of the European Respiratory Society. Eur Respir J Suppl 1993; 16: 5-40. https:// doi.org/10.1183/09041950.005s1693.

24. Balke B. A simple field test for the assessment of physical fitness. Rep 63-6. Rep Civ Aeromed Res Inst US 1963; 1-8. PMID: 14131272.

25. Holland AE, Spruit MA, Troosters T, Puhan MA, Pepin V, Saey D. An official European Respiratory Society/ American Thoracic Society technical standard: field walking tests in chronic respiratory disease. Eur Respir J 2014; 44: 1428-46. Available from: https://doi.org/10.1183/09031936.00150314.

26. Sherpa CT, LeClerq SL, Singh S, Naithani N, Pangeni R, Karki A. Validation of the St. George's respiratory questionnaire in Nepal. Chronic Obstr Pulm Dis 2015; 2: 281-9. Available from: https://doi.org/10.15326/ jcopdf.2.4.2014.0156.

27. López-Campos JL, Fernandez-Villar A, Calero-Acuña C, Represas-Represas C, Lopez-Ramírez C, Fernández VL. Evaluation of the COPD Assessment Test and GOLD patient types: a cross-sectional analysis. Int J Chron Obstruct Pulmon Dis 2015; 975. Available from: https://doi.org/10.2147/COPD.S82781.

28. Voll-Aanerud M, Eagan TML, Wentzel-Larsen T, Gulsvik A, Bakke PS. Respiratory symptoms, COPD severity, and health related quality of life in a general population sample. Respir Med 2008; 102: 399-406. Available from: https://doi.org/10.1016/j.rmed.2007.10.012.

29. Regional well-being (Edition 2016) [Internet]. OECD regional statistics. 2000-2013 [cited 2020 Jan 24]. Available from: https://www.oecd-ilibrary.org/urban-rural-and-regional-development/data/oecd-regionalstatistics/regional-well-being-edition-2016_d147c81c-en.

30. OECD, European observatory on health systems and policies. Hungary: country health profile 2019. Paris: OECD Publishing, Brussels: European Observatory on Health Systems and Policies; 2019 [cited 2020 Jan 24]. (State of Health in the EU; 2019) Available at: https://www.oecd-ilibrary.org/social-issues-migration-health/ hungary-country-health-profile-2019_4b7ba48c-en.

31. OECD, European Union. Health at a glance: Europe 2018: state of health in the EU cycle. Paris: OECD Publishing, Brussels: European Union; 2018 [cited 2020 Jan 24]. Available at: https://www. oecd-ilibrary.org/social-issues-migration-health/health-at-a-glance-europe-2018_health_glance_eur2018-en.

32. Papaioannou AI, Loukides S, Gourgoulianis KI, Kostikas K. Global assessment of the COPD patient: time to look beyond FEV1? Respir Med 2009; 103: 650-60. Available from: https://doi.org/10.1016/j.rmed.2009.01. 001 .

33. Wacker ME, Jörres RA, Karch A, Wilke S, Heinrich J, Karrasch S, et al. Assessing health-related quality of life in COPD: comparing generic and disease-specific instruments with focus on comorbidities. BMC Pulm Med 2016; 16: 70. Available from: https://doi.org/10.1186/s12890-016-0238-9.

34. Kerti M, Balogh Z, Kelemen K, Varga JT. The relationship between exercise capacity and different functional markers in pulmonary rehabilitation for COPD. Int J Chron Obstruct Pulmon Dis 2018; 13: 717-24. Available from: https://doi.org/10.2147/COPD.S153525.

35. Varga J, Boda K, Somfay A. A kontrollált es nem kontrollált alsó végtagi dinamikus tréning hatása krónikus obstruktív tüdőbetegségben szenvedők rehabilitációjában [The effect of controlled and uncontrolled dynamic lower extremity training in the rehabilitation of patients with chronic obstructive pulmonary disease]. Orv Hetil 2005; 146: 2249-55. Hungarian. PMID: 16302356. 
36. Varga J, Casaburi R, Ma S, Hecht A, Hsia D, Somfay A. Relation of concavity in the expiratory flow-volume loop to dynamic hyperinflation during exercise in COPD. Respir Physiol Neurobiol 2016; 234: 79-84. Available from: https://doi.org/10.1016/j.resp.2016.08.005.

37. World Health Organization. Global recommendations on physical activity for health. [Internet]; 2010 [cited 2020 Jun 11]. Available from: http://www.ncbi.nlm.nih.gov/books/NBK305057/.

38. Jenkins C, Rodriguez-Roisin R. Quality of life, stage severity and COPD. Eur Respir J 2009; 33: 953-5. https:// doi.org/10.1183/09031936.00019009.

39. Kim J, Lee C-H, Lee M-G, Shin K-C, Yoo KH, Lim SY. Acute exacerbation according to GOLD 2017 categories in patients with chronic obstructive pulmonary disease. Arch Bronconeumol 2019; 55: 414-20. Available from: https://doi.org/10.1016/j.arbres.2019.02.004.

40. Kunanusornchai W, Wadell K, Janson C, Larsson K, Casaburi R, Lindberg A. The six minute walk distance is the best predictor of physical activity in severe COPD patients [abstract]. Eur Respir J 2017; 50: PA4700. Available from: https://doi.org/10.1183/1393003.congress-2017.PA4700.

41. Pako J, Barta I, Balogh Z. Assessment of the anti-aging klotho protein in patients with COPD undergoing pulmonary rehabilitation. J COPD 2017; 14: 176-80. https://doi.org/10.1080/15412555.2016.1272563.

42. Vágvölgyi A, Rozgonyi Z, Vadász P, Varga JT. A mellkassebészeti mütéti teherbíró képesség megítélése, perioperatív légzésrehabilitáció [Risk stratification before thoracic surgery, perioperative pulmonary rehabilitation]. Orv Hetil 2017; 158: 1989-97. Hungarian. https://doi.org/10.1556/650.2017.30862.

43. Jenkinson C. Comparison of UK and US methods for weighting and scoring the SF-36 summary measures. J Public Health Med 1999; 21: 372-6. https://doi.org/10.1093/pubmed/21.4.372.

Open Access. This is an open-access article distributed under the terms of the Creative Commons Attribution 4.0 International License (https://creativecommons.org/licenses/by/4.0/), which permits unrestricted use, distribution, and reproduction in any medium, provided the original author and source are credited, a link to the CC License is provided, and changes - if any - are indicated. (SID_1) 